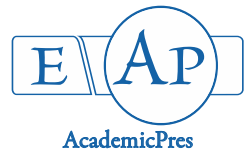

\title{
Assessment of the Effectiveness of Ginger (Zingiber officinale), Clove (Syzygium aromaticum) and Sodium Benzoate on the Shelf Life of Soymilk
}

\author{
Musa O. AREKEMASE*, Deborah R. BABASHOLA \\ University of Ilorin, Department of Microbiology, Kwara, \\ Nigeria; awedaisaac19@gmail.com (*correspondingauthor);Babasholaromo@gmail.com
}

\begin{abstract}
The significance of preservatives in food preparations lies in their ability to inhibit or retard the growth of microorganisms which in turn reduces their deteriorative effects on food. The preservative effects at varying concentrations $(1 \%, 3 \%, 5 \% \mathrm{v} / \mathrm{v})$ of sodium benzoate was compared with extracts of ginger, cloves and a combination of the two extracts on soymilk at refrigerated temperature. Indices for measurement of shelf life included drop in $\mathrm{pH}$, protein and fat contents, changes in colour and odour, as well as changes in microbial counts. The protein, fat contents and $\mathrm{pH}$ decreased more with storage time and these were concentration dependent. The bacterial counts during 25 days of storage ranged from $1.0 \times 10^{4}$ to $6.4 \times 10^{5}$, while fungal counts ranged from $8.0 \times 10^{3}$ to $18.4 \times 10^{4}$. At all concentrations, sodium benzoate exhibited the best preservative effect on the soymilk samples. Reduction in total microbial count was more pronounced in samples treated with clove extract than those treated with ginger extract, while the extracts' combination exhibited the best preservative effect of all the spice treated samples. The use of ginger as a preservative increased shelf life of soymilk by 7 days, cloves extended shelf life by 10 days, while the combination of the extracts maintained a longer shelf life of 13 days. The bacterial isolates include Bacillus cereus Strain KWS2, Bacillus subtilis strain BTBS, Bacillus amyloliquefaciens strain PJ-5, Bacillus safensis strain SABA5 and Lactobacillus fermentum strain SABA5, while the fungal isolates were Aspergillus niger, Aspergilus fumigatus, Fusarium moniliforme and Saccharomyces cerevisae. The phytochemicals found in ginger and cloves include tannins, phenol, alkaloid, flavonoid, terpenoids, steroids, glycosides, coumarin and saponins, which might be responsible for the antimicrobial properties. The results of the study showed that a combination of ginger and cloves extracts is a better preservative of soymilk than the single extracts, as natural preservatives.
\end{abstract}

Keywords: cloves; ginger; phytochemical; preservatives; shelf-life; soymilk

\section{Introduction}

The beneficial effect of protein in the diet of growing infants and its continuous supply is vital in Africa where the occurrence of protein energy malnutrition (PEM) is very rampant (Kabiru et al., 2012). This is because the diets of people in many developing countries comprise mainly of starchy roots, cereals and few legumes. Unfortunately, animal sources of protein, which are used to complement the starchy diets, are limited, scarce and expensive (Kolapo and Oladimeji, 2008).

A lot of legumes and dairy formulated foods were introduced in order to increase the supply of milk and milk product in an environment where there is scarce supply of such products. Since legumes are important sources of relatively inexpensive protein, introduction of imitated milk products from legumes will contribute to the alleviation of protein malnutrition (Gesinde et al., 2008).
Soymilk is free of the milk sugar lactose and is a good choice for people who are lactose intolerant (Dashiell et al., 1990). However, the nutritious nature of soymilk makes it prone to microbial attack and thus has a short shelf life. A large number of microorganisms such as mesophilic aerobic bacteria, coliforms and fungi, are known to be responsible for the spoilage of soymilk, producing undesirable changes (Agboke et al., 2011).The extension of the shelf life of soybean products will help to save both time and labour spent in the preparation (Kabiru et al., 2012). This can be achieved by controlling the growth of spoiling and pathogenic food-related microorganisms.

Preservatives food additives reduce the risk of food borne infections, decreases microbial spoilage and preserve fresh attributes and nutrition. The incorporation of preservative agents to foods has been used for several decades. The efficiency of chemical preservatives is governed by the concentration employed; the formulation of the food 
and nutrients present, as well as the nature or type of microorganisms which is growth, is to be inhibited. The concentration of preservative permitted by food regulation is inhibitory rather than lethal to contaminating organisms, thus it is essential that the micro-biological population of the food to be preserved, is kept to a minimum by hygienic handling and processing (Zamal et al., 2011).

The chemical preservative sodium benzoate, at low concentration, slows down or inhibits the action of the microorganisms. Antibacterial and antifungal effect of benzoate is associated to $\mathrm{pH}$, so that it manifests its antimicrobial action at low $\mathrm{pH}$. Its antimicrobial activity is due to the intact molecule. These compounds are ineffective in neutral $\mathrm{pH}$. The $\mathrm{pKa}$ of benzoate is equivalent to 4.2 and at $\mathrm{pH}$ of 4 , where $60 \%$ of this compound has not been separated, while at $\mathrm{pH}$ equal to 6 only $1.5 \%$ is not separated. Due to this fact, the employment of benzoic acid and its sodium salt is not restricted to products with high-acidity; this acidity is usually enough to prevent the growth of bacteria and act as an effective deterrent force against mold and yeast in food products (Stanojevic, 2009; Shahmohammadi et al., 2016).

However, chemical preservatives have shown to have adverse effect on consumers (Ahn et al., 2007). The disadvantages of sodium benzoate have been approved on human health, which include cell damage (Gonzalez et al., 2010; Beyoglu et al., 2012; Shahmohammadi et al., 2016). This has led to increase concerns of the consumers about foods free or with lower level of chemical preservatives because these could be toxic (Hyldgaard et al., 2012; Gottardi et al., 2016).

Accompanying this, consumers have expressed their desire for foods with long shelf-life and absence of risk of causing foodborne diseases. This perspective has put pressure on the food industry for progressive removal of chemical preservatives and adoption of natural alternatives to obtain its goals concerning microbial safety (Gottardi $e t$ al., 2016). Thus, the essence of natural preservatives over synthetic preservatives, which are less costly and present no toxicological problems and environmental hazards has been of great of interest (Uhart et al., 2006).

Therefore, the aims of the present research work were: (i) to find out the microorganisms causing spoilage of soy milk; (ii)To determine the effectiveness of ginger, clove and chemical preservative (sodium benzoate) on the microbial load of soymilk; (iii)To determine the most effective among the preservatives either singly or in combination.

\section{Materials and Methods}

\section{Extraction of spices}

Ginger rhizomes were peeled, washed, sliced into thin layer and air dried. The cloves were sun dried. Both the dried cloves and the dried ginger rhizome were pulverized with the use of clean electric blender. The extracts were then prepared by soaking $100 \mathrm{~g}$ each of ginger and clove powder into $60 \mathrm{ml}$ distilled water and placed on the shaker for 72 hours at room temperature. Extracts were filtered using filter papers, collected in conical flasks and then stored in refrigerator (Zia-ur-Rehman et al., 2003).
Determination of effects of different preservatives on soymilk samples

The prepared soymilk was dispensed into 13 sterile bottles, 12 of which were treated with preservatives while the $13^{\text {th }}$ bottle served as control. The different preservatives used were clove extract, ginger extract, combination of ginger and clove extract, and sodium benzoate. These preservatives were used at the following concentration: $1 \%$, $3 \%$ and $5 \%$ each. The preservatives were added to the bottled soymilk, labelled properly and refrigerated. They were stored for a period of 30 days.

Total microbial counts of soymilk treated with preservatives

Total bacterial count was determined to assess the number of microbial cells and the effects of different extracts on microorganisms. These were done immediately after production of soymilk and then every 72 hours.

\section{Isolation and characterisation of microorganism associated with spoilage of soymilk}

The method of Fawole and Oso (2004) was used to isolate and characterise microorganism associated with soymilk spoilage.

\section{Total bacterial counts}

One $\mathrm{ml}$ of each soymilk sample was dissolved in $9 \mathrm{ml}$ of distilled water, after which serial dilutions were carried out in five folds aseptically, as described by Fawole and Oso (1988). One $\mathrm{ml}$ of each sample after serial dilution was plated out in duplicates on Nutrient agar (NA) plates using pour plate method and incubated at $37^{\circ} \mathrm{C}$ for 24 hours. Bacterial count was carried out after 24 hours incubation with the aid of a colony counter.

\section{Total fungal counts}

Total fungal counts were also carried out by pour plate method using potato dextrose agar (PDA). One $\mathrm{ml}$ of each soymilk sample was dissolved in $9 \mathrm{ml}$ of distilled water, after which serial dilutions were carried out in five folds aseptically as described by Fawole and Oso (1988). One ml of each sample after serial dilution was plated out in duplicates on potato dextrose agar and incubated at $28{ }^{\circ} \mathrm{C}$ for 48 hours.

\section{Determination of $p H$ of preserved soymilk}

The $\mathrm{pH}$ of the sample was carried out from the onset of storage and monitored every 72 hours. $2 \mathrm{ml}$ of each sample were withdrawn and diluted with $20 \mathrm{ml}$ of distilled water. The $\mathrm{pH}$ values of samples were determined using Phillip PW $9418 \mathrm{pH}$ meter, the instrument was standardized using a buffer solution.

\section{Proximate analysis of the preserved soymilk}

Proximate analysis was carried out from the onset of production and monitored every 72 hours, according to the method described by AOAC (1990).

\section{Determination of crude protein}

The crude protein was determined by the method described by AOAC (1990); $0.5 \mathrm{~g}$ of soymilk sample was 
402

digested with $5 \mathrm{ml}$ of concentrated sulphuric acid in the presence of Kjeldahl catalyst. The nitrogen from the protein in the samples was converted to ammonium sulphate that reacted with $2.5 \mathrm{ml}$ of $2.5 \%$ Brucine reagent; $5 \mathrm{ml}$ of $98 \%$ sulphuric acid were to give a coloured derivative and the absorbance was read at $470 \mathrm{~nm}$. The percentage nitrogen was calculated and multiplied by 6.25 to obtain the value of crude protein.

\section{Determination of crude fat}

The determination of the fat content of treated and untreated soymilk samples was done by mixing the samples with concentrated $\mathrm{HCl}$ acid and heating in the steam bath until the mixture became dark brown. Ether was used to extract the fat in the bath. The ether extract of a sample represented the fat and oil in the sample. The weight of the fat was taken and the fat content calculated on percentage basis (AOAC, 2000).

\section{Determination of titratable acidity of soymilk samples}

Titratable acidity of soymilk samples was determined by measuring $4 \mathrm{ml}$ of soymilk into $250 \mathrm{ml}$ conical flask and 200 $\mathrm{ml}$ of distilled water was added. The flask was allowed to stand in a water bath at $40^{\circ} \mathrm{C}$ for 1 hour; it was then swirled occasionally to ensure complete mixing before filtration. Phenolphthalein was added after filtration and then titrated against $0.1 \mathrm{NaOH}$ solution. The result was expressed as percentage ascorbic acid equivalent present in the beverage.

\section{Phytochemical screening of plant extract}

Phytochemical tests were carried out on the crude extracts of ginger and clove using standard procedures to identify the constitutes present, as described by Awoyinka $e t$ al. (2007).

\section{Results}

The effect of various treatments on the microbial counts of soymilk samples

At all concentration, sodium benzoate was effective throughout the storage period. $5 \%$ ginger + clove preserved the soymilk sample for 13 days, clove for 10 days and ginger for 7 days.

The effect of different treatments on the bacterial counts of soymilk samples

At $1 \%$ concentration, ginger extract had initial bacterial count of $2.0 \times 10^{4}$ and increased to $6.6 \times 10^{5}$ on day 13 after which there was reduction in microbial count throughout the storage period with the final count of $8.0 \times 10^{4}$. Clove had initial bacterial count of $2.0 \times 10^{4}$ which increased to 5.1 $\mathrm{x} 10^{5}$ on day 22 and decreased to $1.2 \times 10^{5}$ on day 25 . Ginger -clove combination had increased bacterial count throughout the storage period from to $1.0 \times 10^{4}$ to $4.2 \times 10^{5}$. This is shown in Fig. 1.

As shown in Fig. 2, 3\% concentration of ginger extract treated sample had initial count of $9.0 \times 10^{4}$, this increased on day 16 to $6.0 \times 10^{4}$, after which there was a reduction in bacterial count throughout the storage period with $1.0 \times 10^{5}$ as the final count. Clove at $3 \%$ concentration had initial count of $6.0 \times 10^{4}$ which reduced to $1.0 \times 10^{4}$ on day four and increased thereafter with the final value of $3.0 \times 10^{5}$, while ginger - clove had initial count of $1.0 \times 10^{5}$ which was reduced to $3.0 \times 10^{4}$ on day 1 and increased throughout the storage period with the final count of $3.8 \times 10^{5}$.

With the concentration of $5 \%$, ginger had the initial count of $5.0 \times 10^{4}$, which reduced to $3.0 \times 10^{4}$ on day 2 and increased throughout the storage period, with the final value of $3.2 \times 10^{5}$. Clove treated sample had the initial count of $1.0 \times 10^{4}$ and final count of $4.8 \times 10^{5}$. Ginger-clove had the initial count of $1.0 \times 10^{5}$, which reduced to $1.0 \times 10^{4}$ on day 1 and increased throughout the storage period with final count of $2.5 \times 10^{5}$. This is shown in Fig. 3 .

The effect of different treatments on the fungal counts of soymilk samples

With $1 \%$ concentration, ginger, clove and ginger-clove treated samples had initial counts of $1.2 \times 10^{4}, 1.1 \times 10^{4}$ and $1.0 \times 10^{4}$ and increased throughout the storage period so that final counts were of $16.4 \times 10^{4}, 12.7 \times 10^{4}$ and $13.5 \times$ $10^{4}$ respectively, as depicted in Fig. 4.

At concentration of $3 \%$, ginger, clove and ginger-clove all had the initial count of $1.0 \times 10^{4}$ and final counts of 15.6 $\times 10^{4}, 12.0 \times 10^{4}$, and $13.0 \times 10^{4}$ respectively as shown in Fig. 5. Soymilk samples with $5 \%$ concentration treatment of ginger, clove and ginger-clove of soymilk treated samples had the initial counts of $9.0 \times 10^{3}, 1.0 \times 10^{4}$ and $8.0 \times 10^{3}$ and increased throughout the storage period, with the final counts of $13.9 \times 10^{4}, 14.0 \times 10^{4}$, and $12.8 \times 10^{4}$ respectively as depicted in Fig. 6.

\section{Effect of various treatments on $p H$ of soymilk samples}

At $1 \%$ concentration of treated samples, sodium benzoate had the highest value of 5.2 with 6.8 as the initial value, while ginger and clove both had the lowest value of 3.2, with the initial value of 6.8. This is shown in Fig. 7.

For 3\% concentration of the treated soymilk samples, sodium benzoate had the highest value of 5.6 with the initial value of 6.7 , which was the highest value recorded for this category. Even more, ginger and ginger-clove had the lowest value of 3.5 both with the initial value of 6.7 and 6.5 respectively. This is shown in Fig. 8

The most effective concentration for all treated samples was $5 \%$. The highest value was recorded for sodium benzoate with 5.5 as the final value and initial value of 6.5, while ginger recorded the lowest value of 3.3 with initial value of 6.8. The control sample had the initial value of 6.9 and final value of 3.0. This is depicted in Fig. 9.

\section{Effect of different treatment on the crude protein of soymilk samples}

The highest value of protein was recorded for soymilk treated samples at $1 \%$ concentration with sodium benzoate and ginger-clove gave initial value of $22.85 \%$ and $24.67 \%$ and final value of $16.1 \%$ and $15.01 \%$ respectively, while ginger had the lowest value of $12.89 \%$ with the initial value of $23.85 \%$. This is shown in Fig. 10.

As shown in Fig. 11, with 3\% concentration treatments, sodium benzoate and ginger-clove had the highest value of 16.20 and 15.62 with initial value of $22.52 \%$ and $24.56 \%$ respectively, while ginger had initial value of $23.62 \%$. and final value of $13.24 \%$ with concentration of $5 \%$, sodium benzoate and ginger-clove had the highest value of 17.68 


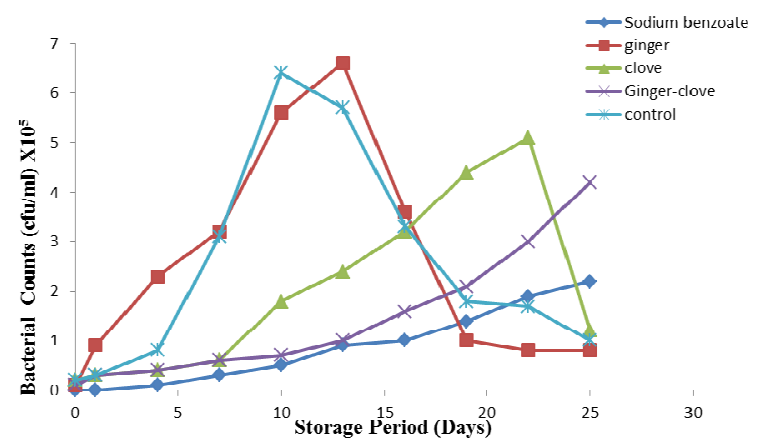

Fig. 1. Effects of different treatments on bacterial counts of soymilk samples at $1 \%$ concentration stored at refrigerated temperature for 25 days

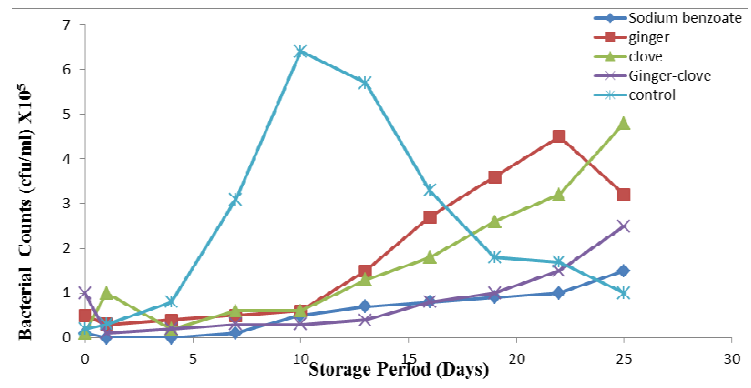

Fig. 3. Effects of different treatments on bacterial counts of soymilk samples at $5 \%$ concentration stored at refrigerated temperature for 25 days

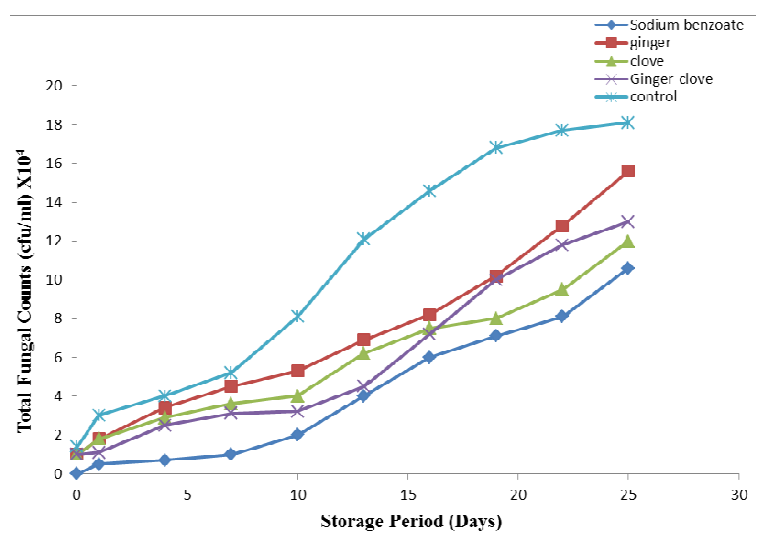

Fig. 5. Effects of different treatments at 3\% concentration on the fungal counts of soymilk samples stored at refrigerated temperature for 25 days

and 15.90 with the initial value of 22.86 and 25.07 respectively, which are the values recorded for this category. Ginger had the lowest value of 13.75 with the initial value of 23.50 .

The control sample had initial value of $22.95 \%$ and final value of $12.01 \%$. This is shown in Fig. 12.

\section{Effect of different treatment on the crude fat of soymilk samples}

The highest value of crude fat recorded for soymilk treated samples at $1 \%$ concentration was sodium benzoate with initial value of $12.62 \%$ and final value of $8.02 \%$, while

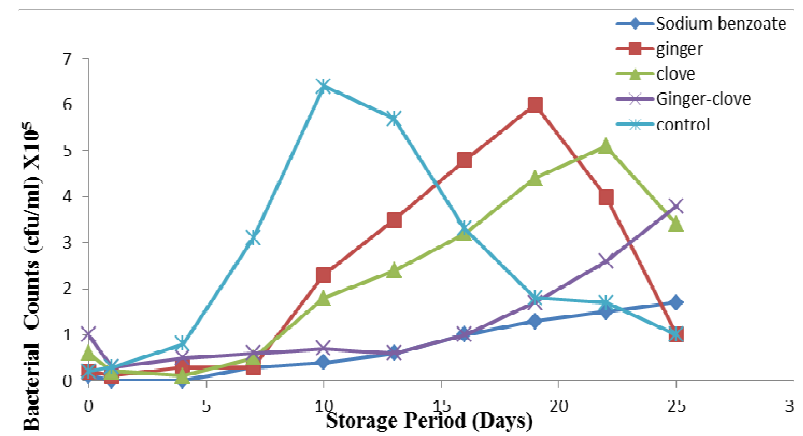

Fig. 2. Effects of different treatments on bacterial counts of soymilk samples at $3 \%$ concentration stored at refrigerated temperature for 25 days

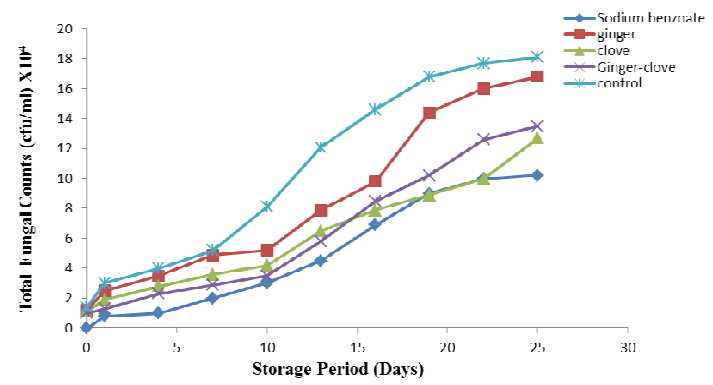

Fig. 4. Effects of different treatments at $1 \%$ concentration on the fungal counts of soymilk samples stored at refrigerated temperature for 25 days

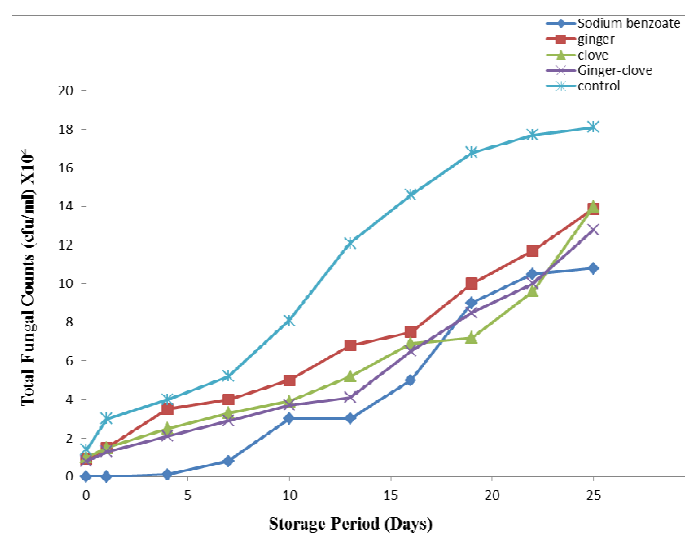

Fig. 6. Effects of different treatments at $5 \%$ concentration on the fungal counts of soymilk samples stored at refrigerated temperature for 25 days

clove had the lowest value of $4.03 \%$ with the initial value of 12.61\% as depicted in Fig. 13.

At 3\% concentration, sodium benzoate preserved soymilk had the highest value of $8.26 \%$ and with initial value of $12.60 \%$, while clove had the lowest value of 4.01 and initial value of $12.72 \%$. This is shown in Fig. 14.

For $5 \%$ concentration, sodium benzoate and gingerclove had the highest value of $8.50 \%$ with the initial value of 12.68, which was the highest value recorded for this category. Ginger had the lowest value of $4.35 \%$ with the initial value of $12.75 \%$, as shown in Fig. 15. The control sample had initial value of $12.64 \%$ and final value of $4.20 \%$. 


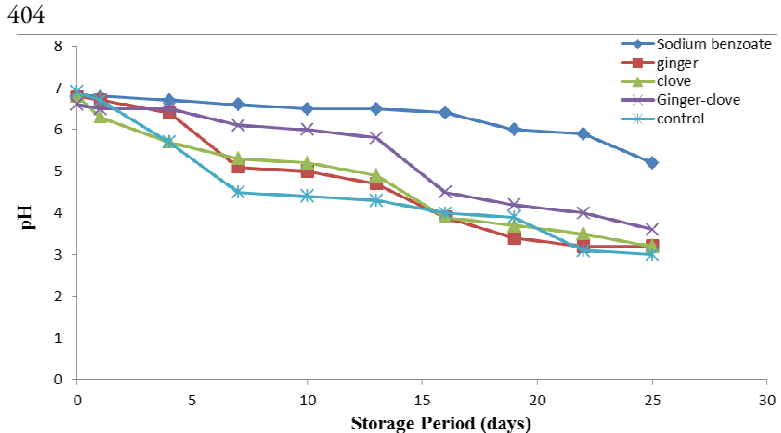

Fig. 7. Effects of different treatments on $\mathrm{pH}$ of soymilk samples at $1 \%$ concentration stored at refrigerated temperature for 25 days

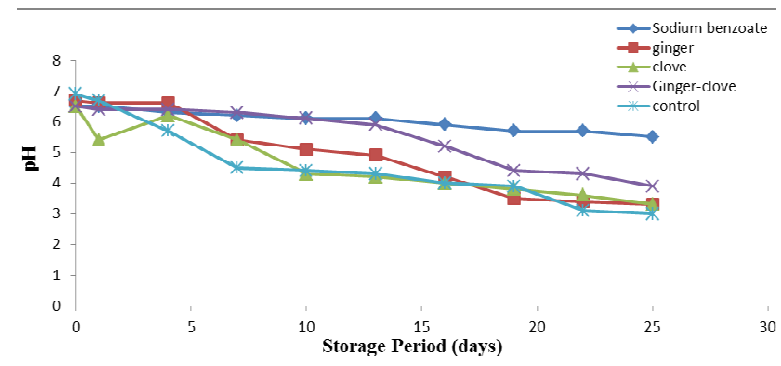

Fig. 9. Effect of different treatments on the $\mathrm{pH}$ of soymilk samples at $5 \%$ concentration stored at refrigerated temperature for 25 days

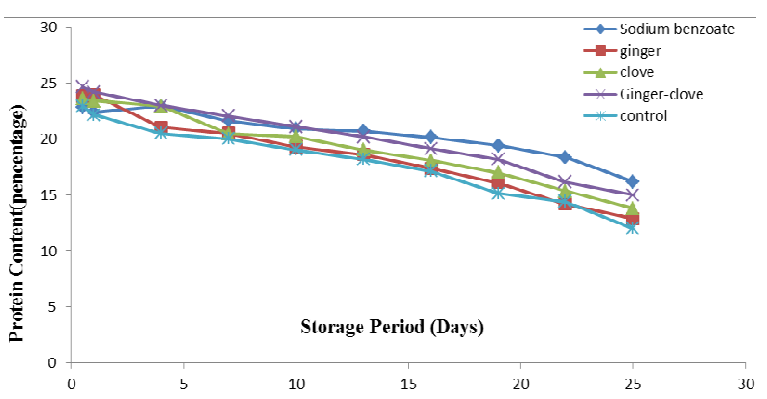

Fig. 11. Effects of different treatments on the protein content of soymilk samples at 3\% concentration stored at refrigerated temperature for 25 days

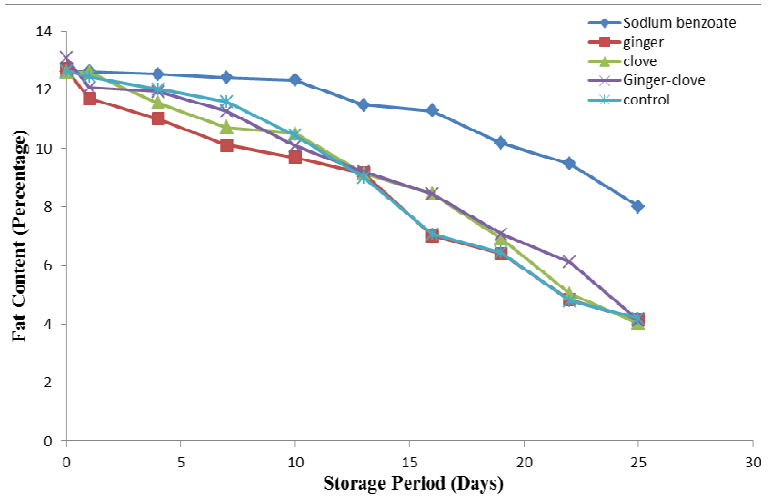

Fig. 13. Effects of various treatments on the fat content of soymilk samples at $1 \%$ concentration stored at refrigerated temperature for 25 days

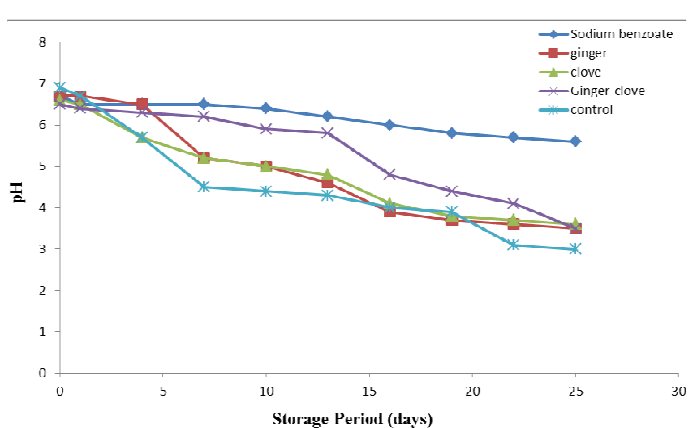

Fig. 8. Effects of different treatments on $\mathrm{pH}$ of soymilk samples at $3 \%$ concentration stored at refrigerated temperature for 25 days

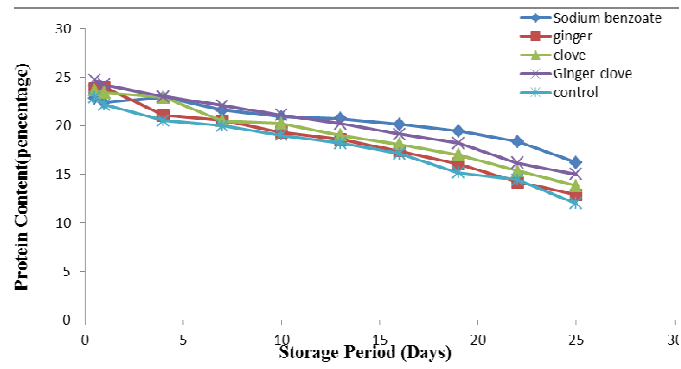

Fig. 10. Effects of different treatments on protein content of soymilk samples at $1 \%$ concentration stored at refrigerated temperature for 25 days

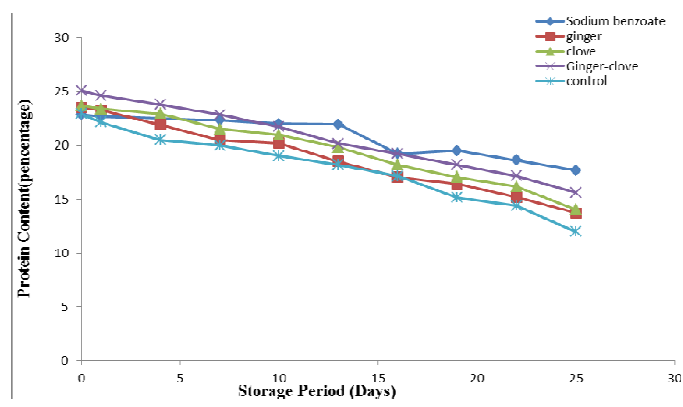

Fig. 12. Effects of different treatments on the protein content of soymilk samples at $5 \%$ concentration stored at refrigerated temperature for 25 days

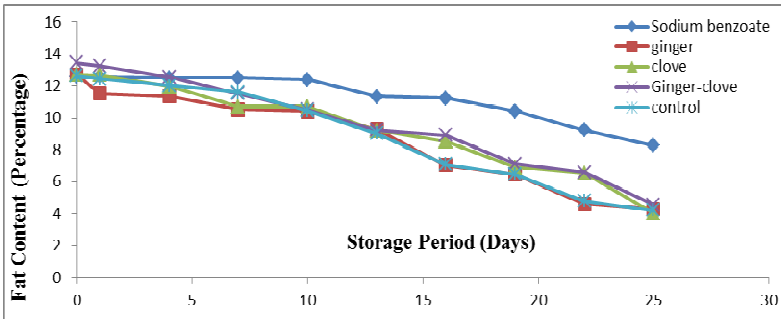

Fig. 14. Effects of various treatments on the fat content of soymilk samples at $3 \%$ concentration stored at refrigerated temperature for 25 days 


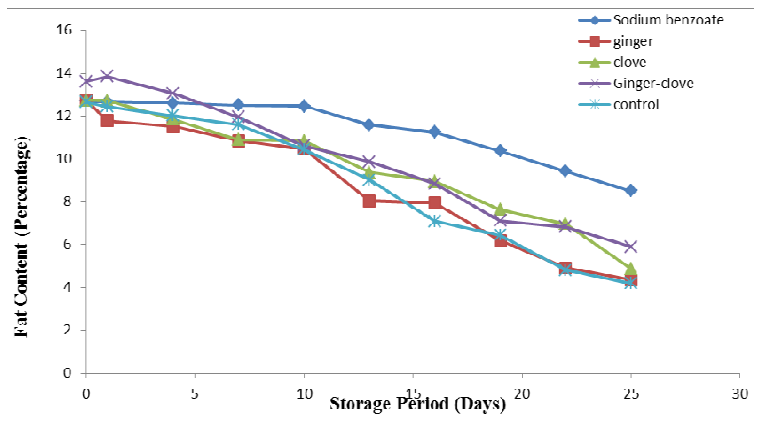

Fig. 15. Effects of various treatments on the fat content of soymilk samples at $5 \%$ concentration stored at refrigerated temperature for 25 days

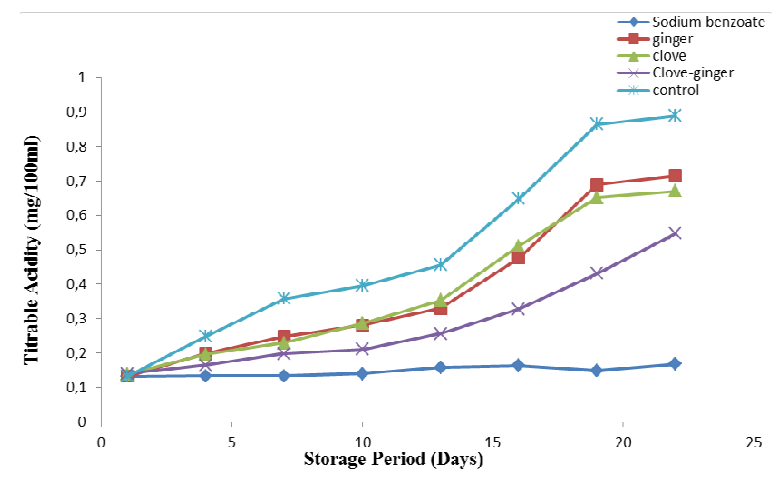

Fig. 17. Effects of various treatments on the titrable acidity of soymilk samples at $3 \%$ concentration stored at refrigerated temperature for 25 days

Effect of different treatment on the titrable acidity of soymilk samples

At the end of the storage period, the highest value of 0.822 was recorded for $1 \%$ ginger treated sample with the initial value of 0.132 , while the lowest value of 0.276 was recorded for $5 \%$ sodium benzoate treated sample with the initial value of 0.131 . The control sample had initial value of 0.132 and final value of 0.956 .

Identification of microbial isolates from spoilt soymilk samples

Identification of bacterial isolates

A total of five bacteria were isolated from spoilt soymilk samples. The results of cultural, morphological and biochemical characteristics of the bacterial isolates from spoilt soymilk samples are presented in Table 1. The isolated bacteria include: Lactobacillus fermentum strain SABA5, Bacillus cereus strain KWS2, Bacillus subtilis strain BTBS, Bacillus amyloliquefaciensstrain PJ-5 and Bacillus safensis strain CR2.

Phytochemicals present in clove and ginger extract

The different phytochemicals found in both ginger and clove extracts are presented in Table 2.

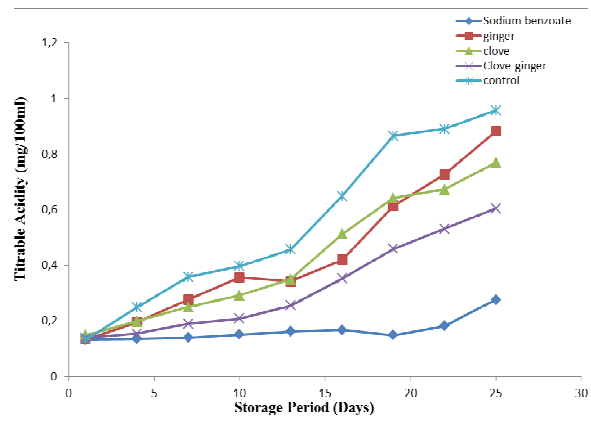

405

Fig. 16. Effects of various treatments on the titrable acidity of soymilk samples at $1 \%$ concentration stored at refrigerated temperature for 25 days

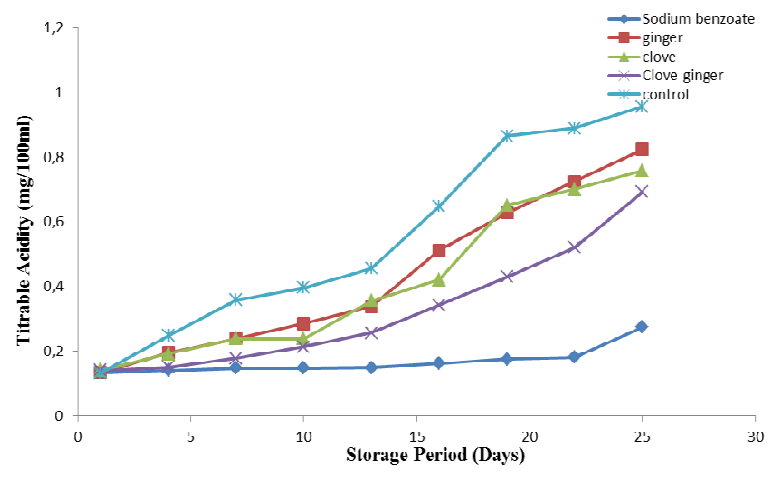

Fig. 18. Effects of various treatments on the titrable acidity of soymilk samples at $5 \%$ concentration stored at refrigerated temperature for 25 day

\section{Discussion}

At all sampling times, all soymilk samples were found to undergo changes in viable bacterial and fungal counts. Lower bacteria and fungi counts were observed in all samples with preservatives as compared to the control sample at each sampling period. There was a general increase in the count with increase in storage period in all the samples. Sodium benzoate and ginger-clove preserved soymilk samples had the least microbial count at all times.

From the shelf life study, it was observed that soymilk sample without any treatment was good for consumption three days after production as compared to the normal 24 hours for unrefrigerated and untreated soymilk. The extension in shelf life might be due to the combined effect of pasteurization and refrigeration. Generally, pasteurization might have destroyed most growing organism in the soymilk product that would have caused the spoilage earlier than was observed and low temperature storage controlled the proliferation of organisms present. The combined effects of pasteurization and refrigeration storage therefore drastically reduced the proliferation of these microorganisms. This concurs with the work of Mbajiuka et al. (2014a), who reported that pasteurized and 
406

Table 1. The cultural, morphological and biochemical characteristics of bacterial isolates from soymilk samples

\begin{tabular}{|c|c|c|c|c|c|}
\hline Isolate & B1 & B2 & B3 & B4 & B5 \\
\hline Colonial characteristics & $\begin{array}{l}\text { Circular, raised, } \\
\text { entire, white }\end{array}$ & $\begin{array}{c}\text { Irregular, cream, flat, } \\
\text { opaque }\end{array}$ & $\begin{array}{c}\text { Irregular, cream, flat, } \\
\text { opaque }\end{array}$ & $\begin{array}{l}\text { Undulate, } \\
\text { irregular, white }\end{array}$ & $\begin{array}{l}\text { Small, circular, } \\
\text { translucent, flat }\end{array}$ \\
\hline $\begin{array}{l}\text { Morphological } \\
\text { characteristics }\end{array}$ & Rod in chains & Rod in chains & Rod in chains & Rod in chains & Long rods in pairs \\
\hline Gram reaction & + & + & + & + & + \\
\hline Spore staining & + & + & + & + & - \\
\hline Catalase & + & + & + & + & - \\
\hline Urease & - & - & - & - & - \\
\hline Citrate & + & + & + & + & - \\
\hline Oxidase & + & + & - & + & + \\
\hline Methyl Red & - & - & - & - & + \\
\hline Voges Proskauer & + & + & + & + & + \\
\hline Glucose & + & + & + & + & + \\
\hline Sucrose & - & + & + & + & + \\
\hline Tentative identity & Bacillus cerues & Bacillus subtilis & Bacillus amyloliquefaciens & Bacillus safensis & Lactobacillus fermentum \\
\hline
\end{tabular}

Table 2. The phytochemicals present in clove and ginger extracts

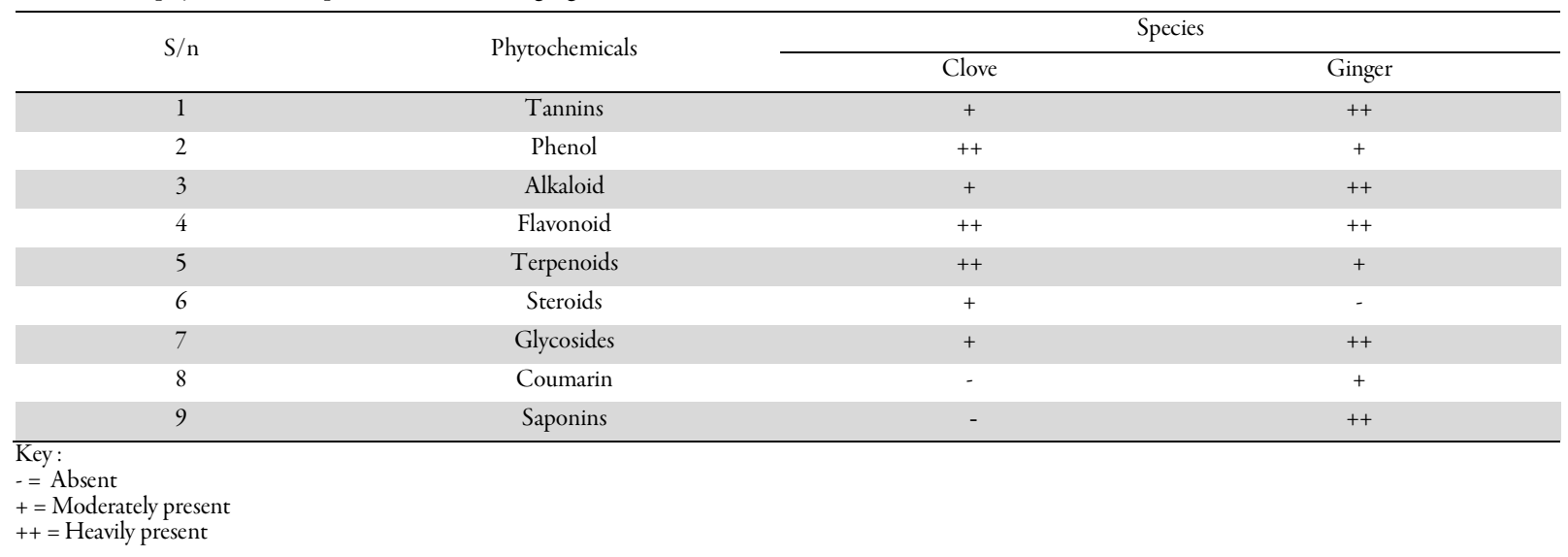

refrigerated soymilk was good for consumption four days after the production day because of the combined effect of pasteurization and refrigeration.

Ginger extract used at 5\% concentration preserved the soymilk sample for 7 days, while $1 \%$ and $3 \%$ preserved the samples for four days. This might be due to the antimicrobial properties of ginger. This result is in accordance with the work of Akponah et al. (2013) who reported the potency of ginger in extending the shelf life of orange juice. The result dovetails with the findings of Adesokan (2014), who reported the effectiveness of ethanolic extract of ginger in prolonging the shelf life of West African soft cheese for up to 3 days. This is also in agreement with the work of Obi (2015), who reported that the prolonged shelf life of ginger treated zobo drink for 6 days at room temperature was due to it antimicrobial property the effectiveness of ethanolic extract of ginger in prolonging the shelf life of West African soft cheese for up to 3 days. This is in also agreement with the work of Obi (2015), who reported that the prolonged shelf life of ginger treated zobo drink for 6 days at room temperature was due to it antimicrobial property.

Clove treated samples at 3\% and 5\% concentration, preserved the soymilk for 10 days, while $1 \%$ preserved it for 10 days. This result is supported by the work of Kabiru $e t$ al.
(2012) who reported that soymilk samples might be preserved with clove extract for up to 8 days in the refrigerator. There was a moderate reduction in microbial load of clove treated samples when compared with those of ginger treated samples, showing that clove spice has more antimicrobial activity than ginger.

Although ginger and clove resulted in decrease in microbial counts as compared to the control, the combination of the two showed higher efficacy than the single spices and extended the shelf life of soymilk for 13 days thus indicating synergistic action of the two extracts. This concurs with the work of Kabiru et al. (2012), they reported that the combined effect of clove and Guineapepper exert more preservative action on soymilk sample as compared to single application of the spices in soymilk samples. Edward (2012) and Mbajiuka et al. (2014) have also reported similar synergistic effects of ginger and garlic in extending the shelf life of "kunun-zaki" and" burukutu" respectively.

It was observed that there was a linear reduction in the bacterial load with increase in concentration of spices; the result is in accordance with the work of Udensil et al. (2012) who discovered a reduction in microbial counts with increase in concentration of ginger and black pepper in soymilk samples. It is also in agreement with the work of 
Sagdic et al. (2003a); they found a decrease in microbial load with increasing concentration of Zingiber officinale (ginger), Monodora myrystica (Ehuru) and Syzygium aromaticum in zobo drinks. However, the preservative ability of the spices decreased with increase in length of storage period. This might be due to microbial degradation, particularly in the presence of Lactobacillus. This observation has been reported earlier by Edward (2012) in preservation of ginger and garlic on the microbial load and shelf life of 'kununzaki'.

Soymilk samples preserved with sodium benzoate at all concentration exhibited the best preservative effect, although higher antimicrobial activity was observed at 5\% sodium benzoate. Similar finding has been reported by Odu et al. (2012); they reported that the shelf life of soymilk can be extended up to 16 days in refrigerator in combination with addition of sodium benzoate. This might be due to the mechanisms of action of sodium benzoates through inhibition of microbial cellular uptake of substrate molecules (Vwioko et al., 2013).

The microbial counts data obtained from soymilk samples suggest that the natural preservatives were less effective in prolonging the shelf life compared to sodium benzoate preservative. The reason for this observation might be due to decrease in $\mathrm{pH}$ observed in the samples, as sodium benzoate antimicrobial potency increased as the $\mathrm{pH}$ decreased. A similar finding has been reported by Vwioko et al. (2013) in comparison of ginger and garlic with sodium benzoate on the shelf life of soursop juice.

All the treatments showed a higher suppressive action against fungal, than the bacterial isolates. The findings agree with those of other workers including Kaushik and Goyal (2011), Hassan et al. (2012) and Akponah et al. (2013). Akponah et al. (2013) reported all the extracts of ginger, garlic and rosemary exhibited more antimicrobial action against fungal isolates than the bacterial isolates. Hassan $e t$ al. (2012) research work point to the fact that the antifungal effects might be due to monoterpene, which destroy the integrity of fungi membrane.

The inability of the ginger, clove and a combination of ginger-clove extract to completely inhibit fungal and bacterial growth might be due to the low concentration of the extracts used, as higher concentrations of plant extracts were required before antimicrobial properties were observed (Kabiru et al., 2012). In addition, it was observed that many spices have the ability to inhibit microbial growth in food than in culture media (Shelef, 1983). However, large amounts of the spice extracts required for complete microbial inhibition would affect the organoleptic properties of the milk product (Kabiru et al., 2013).

The initial $\mathrm{pH}$ of all the samples was near to neutrality and decreased gradually with storage time. The reduction in $\mathrm{pH}$ might be due to the fact that the initial $\mathrm{pH}$ of the soymilk samples favoured the growth of many bacteria and then led to subsequent release of metabolic products into the medium. The $\mathrm{pH} 7.2$ for soymilk as reported by Adeleke et al. (2000) and Udensil et al. (2012) falls within the range obtained in thie current study, which incidentally favoured bacterial growth. Adeleke et al. (2000) reported 7.2 as initial $\mathrm{pH}$ of soymilk sample, while Udensil et al. (2012) reported 6.8 as the initial $\mathrm{pH}$ of soymilk sample.
The crude protein and fat contents decreased for all the samples. Decrease in protein probably might be due to the breakdown of protein by proteolytic enzymes released by microorganisms present in the samples, while fat decrease might be as a result of lipid oxidization by the same microorganisms (Aworth and Egounlety, 1985).

The control had the highest decrease in protein and fat content, while sodium benzoate and ginger-clove treated samples recorded the highest value. This might to due to the antioxidant properties of ginger, cloves and sodium benzoate. These spices scavenge super-oxide anions and inhibit lipid oxidation. This observation is supported by the work of Odu (2012) who recorded that prevention of lipid oxidation in soymilk samples was due to the antioxidant property of sodium benzoate incorporated into them. Also, Dorman et al. (2000) reported that ethanol extract of the clove buds showed remarkable scavenging activity, as compared with synthetic antioxidants such as butylated hydroxyl. Kikuzaki et al. (1994) and Belewu (2005) have also reported that most of the isolated compounds from ginger exhibited stronger antioxidant effect than alphatocopherol (vitamin E).

It was observed that in all the samples, total titrable acidity had a uniform increasing trend, although samples preserved with sodium benzoate and 5\% ginger-clove recorded the least value, while the control samples recorded the highest value at all sampling periods. It was also observed that titrable acidity increased with decrease in $\mathrm{pH}$ of the samples. Similar increasing trend of titrable acidity with a decrease in $\mathrm{pH}$ was observed in soymilk samples preserved with local spices during storage by Oroniran et al. (2011).

Microbial growth causes degradation of food quality which leads to visible changes in colour, odour and texture. With the exception of sodium benzoate preserved samples, changes in colour, flavour, taste, whey separation and acid production were observed in the preserved soymilk samples at different time intervals.

The microorganisms isolated include: Bacillus cereus strain KWS2, Bacillus subtilis strain BTBS, Bacillus amyloliquefaciens strain PJ-5, Bacillus safensis strain SABA5 and Lactobacillus fermentum strain SABA5. Mbajuika et al. (2014a) had isolated lactic acid bacteria from soymilk samples stored at refrigeration temperature. Udensil $e t$ al. (2012) also reported similar isolates of Bacillus cereus and Lactobacillus species in soymilk. The occurrence of Bacillus sp. and presence of Lactobacillus sp. might have initiated spoilage in the soymilk and the noticeable increase in acid production. The prevalence of Bacillus sp. might be as a result of their ability to produce spores; this is because pasteurization is not sufficient to inactivate microbial spores. Their ability to tolerate acidity might also be a contributing factor. The near anaerobic condition of stored soymilk samples due to the use of airtight bottles might have also caused micro ecological evolution of microbes isolated. Vwioko et al. (2013) reported that the presence of fermenters such as Bacillus and Saccharomyces in airtight soursop juice might be as a result of the anaerobic environment.

The fungal isolates include: Aspergillus niger, Aspergillus fumigatus, Fusarium moniliforme and Saccharomyces cerevisae. These set of fungi have also been reported in 
408

soymilk samples by Mbajiuka et al. (2014). Odu et al. (2012) also reported that the dominant fungal flora associated with spoilage of soymilk include Saccharomyces cerevisae and Aspergillus sp. The sources of contamination might be soil, air, the handler, food accessories, method of production and storage condition.

The phytochemical screening of ginger and clove extracts showed the presence of tannins, phenol, alkaloid, flavonoid, terpenoids, steroids, glycosides, coumarin and saponins. The antimicrobial activities of ginger and clove might be due to these phytochemicals. This finding agrees with those of other workers Udensil et al. (2012) and Obi (2015).The findings of Udensil et al. (2012) suggest that the preservative effect of ginger and black pepper on soymilk was as a result of their essential oil fraction which was inhibitory to microbial growth. Obi (2015) reported that the antimicrobial activity of spice in zobo drink was as a result of their volatile oil.

The study confirms that the use of sodium benzoate, aqueous extracts of ginger, clove and combination coupled with refrigeration and pasteurization might extend the shelf life of soymilk. The shelf life extension means enhanced commercial potential of soymilk.

\section{Conclusion}

Due to the awareness of chemical preservatives on health and increased concern of the consumers about foods free or with lower level of chemical preservatives, the extracts of these spices represent an alternative source of natural antimicrobial substances for use in food systems to prevent the growth of foodborne microorganisms and extend the shelf-life of the processed food.

\section{Conflict of Interest}

The authors declare that there are no conflicts of interest related to this article.

\section{References}

Adeleke OE, Adeniyi BA, Akinrinmisi AA (2000). Microbiological quality of local soymilk. A public health appraisal. African Journal of Biomedical Research 3:89-92.

https://www.ajol.info/index.php/ajbr/article/view/140721

Adesokan IA (2014). Preservative activity of ethanolic extract of ginger in wara, a West African traditional soft cheese. Journal of Food Technology Research 1(1):45-51.

https://doi.org/10.18488/journal.58/2014.1.1/58.1.45.51

Agboke AA, Uduma E, Osonwa C, Emmanuel O, Ibezim C (2011). Evaluation of microbiology quality of some soybean milk products consumed in Nigeria. Prime Journals 1(2):25-30.

https://doi.org/10.4314/jpb.v8i1.6

Ahn J, Graun I, Mustapha A (2007). Effect of plant extract on microbial growth, colour change and lipid oxidation in cooked beef. Food Microbiology 24(1):7-14.

https://doi.org/10.1016/j.jm.2006.04.006

Akponah E, Okoro IO, Ubogu M, Ejukonemu FE (2013). Effects of ethanolic extracts of garlic, ginger and rosemary on the shelf-life of orange juice. International Journal of Agricultural Policy and Research 1(7):197204.

https://journalissues.org/wp-content/uploads/2013/09/Akponah-etal.pdf

AOAC (1990). Official methods of analysis. (15th Ed). Association of analytical chemist Washington D.C., USA. https://doi.org/10.1016/0165-9936(90)87098-7

AOAC (2000). Ash and fat analysis (gravimetric method). In: Official methods of analysis. NO.33.2.10. AOAC International, Gathersburg, Maryland,USA.

Awort OC, Egounlety M (1985). Preservation of West African soft cheese by chemical treatment. Journal of Dairy Resources 52:189-195. https://doiorg/10.1017/s0022029900024018

Awoyinka O, Balogun IO, Ogunnowo AA (2007). Phytochemical screening and in vitro bioactivity of Cnidoscolus aconitifolius (Euphorbiaceae).Journal of Medical Plant Research 1(3):67-65.

http://www.academicjournals.org/app/webroot/article/article13803704 03_Awoyinka\%20et\%20al.pdf

Belewu MA, Belewu KY, Nkwunowo CC (2005). Effect of biological and chemical preservatives on the shelf life of West African soft cheese. African Journal of Biotechnology 4(10):1076-1079.

Beyoglu D, Idle JR (2012). The gycine deportation system and its pharmacological consequences. Pharmacology Thermal 135(2):151167.https://doi.org/10.1016/j.pharmthera.2012.05.003

Dashiell KE, Singh SR, Nakaayama O, Ogundipe HO, Akeem CN (1990). Soybean research at IITA GLIP. Research monograph No. 1, Ibadan, Nigeria.

Dorman JD, Surai P, Deans SG (2000a). In vitro antioxidant activity of a number of plant essential oils and phytoconstituent. Journal of Essential Oil Research 12:241-248.

https://www.tandfonline.com/doi/abs/10.1080/10412905.2000.9699 508? ?eedAccess $=$ trueerjournalCode $=$ tjeo 20

Edward KC (2012). The effect of ginger and garlic on microbial load and shelf life of Kunnun-zaki. Journal of Applied Pharmaceutical Science 2(5):150-153. https://doiorg/10.7324/japs.2012.2538

Fawole MO, Oso BA (1998). Laboratory manual of microbiology. Spectrum books Limited, Ibadan, Nigeria pp 26-31.

Gesinde AT, Ovawove OM, Adebisi A (2008). Comparative studies on the quality and quantity of soymilk from different varieties of soybean. Pakistan Journal of Nutrition 7(1):157-160. https://doi.org/10.3923/pjn.2008.157.160

Gonzalez KC, Sagebin FR, Oleveira PG, Glock L (2010). A retrospective study analysis of urinary hippuric acid levels in occupational toxicology exams. Ciencia \& Saude Coletiva 1(1):1637-1641.

http://www.scielo.br/scielo.php?script=sci_arttext`opid=S141381232010000700075 \& $\ln g=p t \& t \operatorname{lng}=p t$

Gottardi D, Bukvicki D, Prasad S, Tyagi AK (2016). Beneficial effects of spices in food preservation and safety. Frontiers in Microbiology 7:13-94. https://doiorg/10.3389/fmicb.2016.01394

Hassan HA, Raaul AM, Razik BM, Hassan BA (2012). Chemical composition and antimicrobial activity of the crude extracts isolated 
from Zingiber officinale by different solvents. Journal of Pharmaceutical Analysis 3(9):184-188.

https://doi.org/10.4172/2153-2435.1000184

Hyldgaard M, Mygind B, Meyer RI (2012). Essential oils in food preservation, mode of action, synergies and interaction with food matrix components. Frontiers in Microbiology 3:12.

https://doi.org/10.3389/fmicb.2012.00012

Kabiru YA, Makun HA, Saidu AN, Muhammad LH, Nuntah LC, Amoo SA (2012). Soymilk preservation using extracts of cloves (Syzygium aromaticum Myrtaceae) and guinea-pepper (Xylopia aethiopica Annonaceae).Journal of Pharmacy and Biological Sciences 3(5):4450. https://doi.org/10.9790/3008-0354450

Kaushik P, Goyal P (2011). Evaluation of various crude extracts of Zingiber officinale rhizome for potential antibacterial activity: a study in vitro. Advance Microbiology 1:7-12.

https://doi.org/10.4236/aim.2011.11002

Kikuzaki H, Kawasaki Y, Nakatani N (1994). Structure of antioxidative compounds in ginger.American Chemist Society. Washington District, USA pp 237-243.

https://doi.org/10.1021/bk-1994-0547.ch024

Kolapo AL, Oladimeji GR(2008). Production and quality evaluation of soycorn milk.Journal of Applied Biosciences 1(2): $40-45$.

http://www.m.elewa.org/JABS/2008/2/Abstract2-Kolapo.html

Mbajiuka CS, Obeagu EI, Ifediora AC, Ugwu GU (2014a). Isolation and identification of microorganisms involved in the spoilage of soymilk. Journal of Pharmacy and Biological Sciences 9(5):29-36.

Mbajuika CS, Obeagu EI, Ochei KC, Onyemairo NC (2014b). Effect of ginger and garlic on the microbial shelf-life of Burukutu. International Journal of Microbiological Research 5(2):117-123.

$\mathrm{ObiCD}$ (2015). Assessment of the preservative effects of different local spices and their flavor acceptability in Hibiscus sabdariffa calyx drinks. International Journal of Agriculture and Rural Development 18(1):2161-2165.

Odu NN, Egbo NN (2012). Assessment of the effect of different preservatives on the keeping quality of soymilk stored at different temperatures. Nature and Science 10(9):1-9.
Oroniran OO, Olunlade BA, Otegbayo BO (2011). Spices as natural preservative in milk. In: Enujiugha VN (6th ed). Book of abstracts. Nigeria Institute of food science and technology, Western chapter half yearly conference. Federal University of Technology, Akure, Ondo State, Nigeria pp 21-22.

Sagdiç O, Karahan AG, Ozcan M, Ozcan G (2003a). Effect of some spices extracts on bacterial inhibition. Food Science and Technology International 9:353-359. bttps://doi.org/10.1177/1082013203038976

Shahmohammadi M, Javadi M, Nassiri-Asl M (2016). An overview on the effects of sodium benzoate as a preservative in food products. Biotechnology and Health Science 3(3):35-84.

https://doiorg/10.17795/bhs-35084

Shelef LA (1983). Antimicrobial effects of spices. Journal of Food Safety 6:29-44. https://doi.org/10.1111/j.1745-4565.1984.tb00477.x

Stanojevic D, Comic L, Stefanovic O, Solujic-Sukdolak S (2009). Antimicrobial effects of sodium benzoate, sodium nitrite and potassium sorbate and their synergistic action in vitro. Journal of Agricultural Science 15(4):307-311.

Uhart M, Maks N, Ravishankar S (2006). Effect of spices on growth and survival of Salmonella typhimuriumdt 104 in ground beef stored at $4{ }^{\circ} \mathrm{C}$ and $8^{\circ} \mathrm{C}$. Journal of Food Safety26(2):115-125.

https://doi.org/10.1111/j.1745-4565.2006.00036.x

Vwioko DE, Osemwegie OO, Akawe JN (2013). The effect of ginger and garlic phytogenics on the shelf life and microbial contents of homemade soursop (Annona muricata L.) fruit juice. International Journal of the Nigeria Society for Experimental Biology 25(2):31-38.

Zamal SS, Uddin MB, Huda MS, Hannan A, Choudhury RU (2011). Effect of preservatives on the shelf-life of soymilk. Journal of Eco-Friendly Agriculture 8(2):23-38.

Zia-ur-Rehman A, Salariya M, Habib F (2003). Antioxidant activity of ginger extract in sunflower oil. Journal of the Science of Food and Agriculture 83:624-639.

https://doi.org/doi:10.1002/jsfa.1318 